\title{
Detection of Total Flavenoids, Reductive Ability, and Anti-microbial in Glycyrrhiza and Achillea Medicinal Plants
}

\author{
Ruqaya M. I. Al-Ezzy \\ University of Al-Nahrain /College of Biotechnology Jadria Iraq
}

Farah T.O. AL-Jumaili

University of Al-Nahrain /College of Biotechnology Jadria Iraq

Nabeel K.Al-Ani (Corresponding author)

University of Al-Nahrain /college of Biotechnology Jadria Iraq

E-mail: nkalani54@yahoo.com

Received: May 28, 2017 Accepted: June 26, 2017 Published: July 19, 2017

doi:10.5296/jbls.v8i2.11297ＵRL: https://doi.org/10.5296/jbls.v8i2.11297

\begin{abstract}
According to WHO, $80 \%$ of the medicine in the global market are from plants. The Glycyrrhiza glabra and Achillea mellofolium are very promising plants. Three experiments were done for these plants. The total flavenoids, was higher in G.glabra than A.mellofolium. In the second experiment, reductive ability was very effective in scavenger the free radical specially, in high doses. In the third experiment, the antimicrobial of the three types of bacteria isolated from two sources assess using extracts from plants.
\end{abstract}

Keywords: Achillea mellefolium, Glycyrrhiza glabra, medicinal plants,total flavenoids, reductive ability, antimicrobial activities

\section{Introduction}

The majority of people rely on their folk medicine for their everyday health care needs. It is a fact that one quarter of medical prescriptions based on substances derived from plants or plant-derived synthetic analogs. $80 \%$ of the world populations, especially those from developing countries, rely on their medicines on plants According to the World Health 
Organization (WHO). (Gurib-Fakim, A., 2006). This is relying on the fact that medicinal plants contain mixtures of different chemical compounds that may act individually, or in synergy to improve health. Nevertheless, they have subjected to an intensive investigation to reveal their pharmaceutical potentials (Yang, Y. \& et al., 2013).

Scientific studies confirmed that the medicinal plants have potentials, and presented in vitro and in vivo. Evidences that medicinal plants or their secondary metabolites have shown different biological effects with a wide range of pharmacological properties; for instance, immune stimulator, antibacterial, anti-viral, anti-oxidant, anti-inflammatory, anti-mutagenic, anticancer, and many other properties (Chan, J. M. \& et al., 2005; Butler, M. S. \& Newman, D. J., 2008; Soladoye, M. O. \& et al., 2010).

Two plants had been used in this study: Licorice (Glycyrrhiza glabra L.; Family: Papilionaceae/Fabaceae) is a traditional medicinal herb grown in the various parts of the world. It is an herb, which is sweet, moist, soothing that detoxifies and protects the liver and it is a powerful anti-inflammatory finds applications in arthritis and mouth ulcers. The plant $2 \mathrm{~m}$ height, the roots are long, cylindrical, thick and multi-branched, very sweet (Scientific, C.o., I. R., 1985).

Te other plant used in this experiment is The genus Achillea mellefolium which is represented by about 85 species throughout the world and 42 of them are found in the flora of Turkey; $23^{\text {th }}$ of these are endemics (Davis, P., \& et al., 1988; Güner, A. \& et al.). Achillea spp used for healing during the previous War (1). Their vegetative parts are used in folk medicine for the treatment of several diseases, disorders and ailments (Skočibušić, M. \& et al., 2004). This plant has some properties and used in cosmetics, fragrances and agriculture (Senatore, F. \& et al., 2005).

Some Achillea spp. was used as antibacterial, anti-inflammatory, cytotoxic and haemostatic agents. Achillea millefolium is used as a laxative,antiviral,anti -inflammatory,anthelmintic, antispasmodic, contraceptive, diuretic, diaphoretic, emenagogue, antipyretic, stimulant and for throat and head ache, hysteria, rheumatism and stomach ulcer.(Duke, J. A., 1992; Kürkçüoğlu, M. \& et al., 2003). Flowers of A. ageratum are used in intestinal disorders and aerial parts of the same plant were reported to have cytotoxic activity. For all the above reasons, we choose these two plants to study their active compounds and the reductive activity.

\section{Material and Methods}

\subsection{Plant Extract Preparation}

Fifty grams of the air-dried plant leaf powder were, extracted with $80 \%$ methanol $(250 \mathrm{ml})$ at $65^{\circ} \mathrm{C}$ for 3 hours using the souxhlet apparatus according to (Sokmen, A., Jones \& et al., 1999). The extract solution was concentrated under reduced pressure in a rotary evaporator to yield dried crude extract which, which was frozen at $-20^{\circ} \mathrm{C}$ until used (Fu, W. \& et al., 2010).

Three doses of the extract were tested $(100,200$ or $300 \mathrm{mg} / \mathrm{ml})$ in vitro. The selection of concentration was based on a previous investigation (Kumar, A. \& et al., 2010). To prepare 
these doses, the dried methanolic extract was, dissolved in a few drops of DMSO (Dimethyl sulfoxide) and then diluted with distilled water to the required volume.

\subsection{Source of Bacteria Isolate and Identification}

Two sources for bacteria isolated had been used 1. Wound infection patients in Al-kindi hospital Baghdad Iraq for proteus and klebsiella spp. 2. Enterobacter spp. was isolated from skimmed milk"Novelac" for babies in local market. Vetik kit used to identify these bacteria .

\subsection{Total Flavonoids Determination}

Total flavonoids content was spectrophotochemically determined in the methanolic extract of the tested plants as Rutin (Total flavenoids) equivalent by aluminium chloride colorimetric method as described by (Sakanaka, S. \& et al., 2005). The methanolic extract (3.2 mg) was dissolved in $5 \mathrm{ml}$ of $50 \%$ methanol.Then, addition of $1 \mathrm{ml}$ of a $5 \%$ (w/v) sodium nitrite solution. After $6 \mathrm{~min}, 1 \mathrm{ml}$ of a $10 \%(\mathrm{w} / \mathrm{v})$ aluminium chloride solution was added and the mixture was allowed to settled for 5 minutes before $10 \mathrm{ml}$ of a $10 \%(\mathrm{w} / \mathrm{v}) \mathrm{NaOH}$ solution was added. The mixture was completed to $50 \mathrm{ml}$ with distilled water and mixed well. Then, the absorbance was measured at $450 \mathrm{~nm}$ with a spectrometer after $15 \mathrm{~min}$. A similar procedure was applied to six concentrations $(2.5,5,10,20,40$ and $80 \mu \mathrm{g})$ of rutin, and from which a standard curve was prepared. The Rutin content ( as total flavenoids) was determined using a curve-fitting equation of the standard curve which is $\mathrm{Y}=0.0012 \mathrm{x}+0.1109 \mathrm{R} 2=0.9317$ (R. M. I. A. -E., 2015).

Assessment of Anti-oxidant Activity in vitro Anti-oxidant activity of the tested plants, methanolic extract was in vitro assessed through the evaluations, of reductive ability radical scavenging activity.Reductive Ability preparation

\section{Method}

The method described by (Fu, W. \& et al., 2010) was adopted to evaluate the reductive ability, in which $1 \mathrm{ml}$ of each concentration of the plant extract $(0.02,0.04,0.08,0.16,0.32$ and 0.64 $\mathrm{mg} / \mathrm{ml}$ ) was mixed with $1 \mathrm{ml}$ of $0.2 \mathrm{M}$ phosphate buffer at $\mathrm{pH} 6.6$ and $1.5 \mathrm{ml}$ of $1 \%$ potassium ferricyanide. Then, the extract incubated at $50^{\circ} \mathrm{C}$ for 20 minutes. $1 \mathrm{ml}$ of $10 \%$ Trichloro acetic acid, was added to the mixture to stop the reaction. The mixture centrifuged for 10 minutes at $3000 \mathrm{rpm}$, and $2.5 \mathrm{ml}$ of the supernatant mixed with $2 \mathrm{ml}$ of distilled water and $0.5 \mathrm{ml}$ of freshly prepared $1 \%$ Ferric chloride. After that, the absorbance measured at $700 \mathrm{~nm}$. The same procedure applied to Trolox solutions (standards). All tests were done in triplicates.

\section{Results and Discussion}

Three experiments represented in this study:

The total flavenoids was assessing for both plants. The results in figure 1 indicate great differences between both plants used. The flavenoids have an interest as dietary constituents; however in clinical studies indicate their roles in preventing cardiovascular disease and many kinds of cancer (Chu, Y. H. \& et al., 2000). In other studies flavenoids and phenolics compounds have an efficient free radical scavenger activity besides some lipid peroxides 


\section{Macrothink}

inhibitors (Egert, S. \& Rimbach, G., 2011). Therefore, increasing flavenoids in both plants may be attributing to the increasing of reductive abilities of these plants (Franco, M. N. \& et al., 2014).

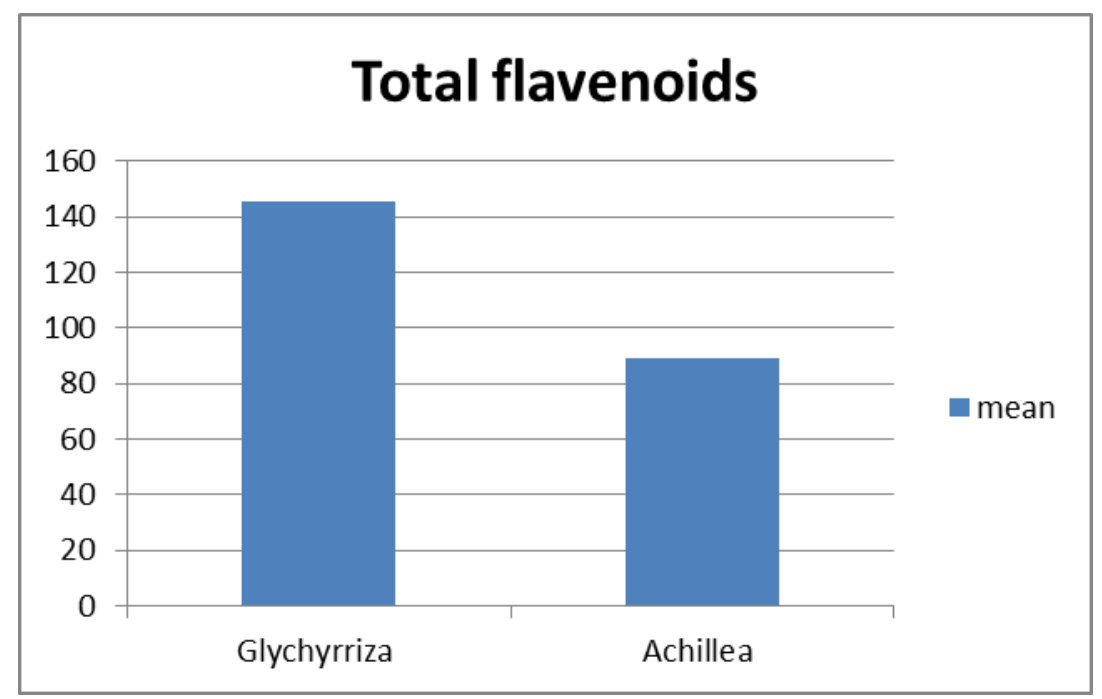

Figure 1. The total flavonoids for Glychrriza spp, Achillea spp.

In the second experiment calculation of reductive ability of the plants which had been used. As noted from figure 2 the R.ability decrease as the concentration of the extract get low in both plants used. It is, well known that free radicals can cause diseases by lipid, protein peroxidation or by DNA damage, however, many plants extracts have antioxidant activities which prevent free radicals from causes any disease. (Hsu, C.-Y. \& et al., 2007). Moreover, phenols found a large quantities in plants and have antioxidant activity (Cocetta, G. \& et al., 2015).

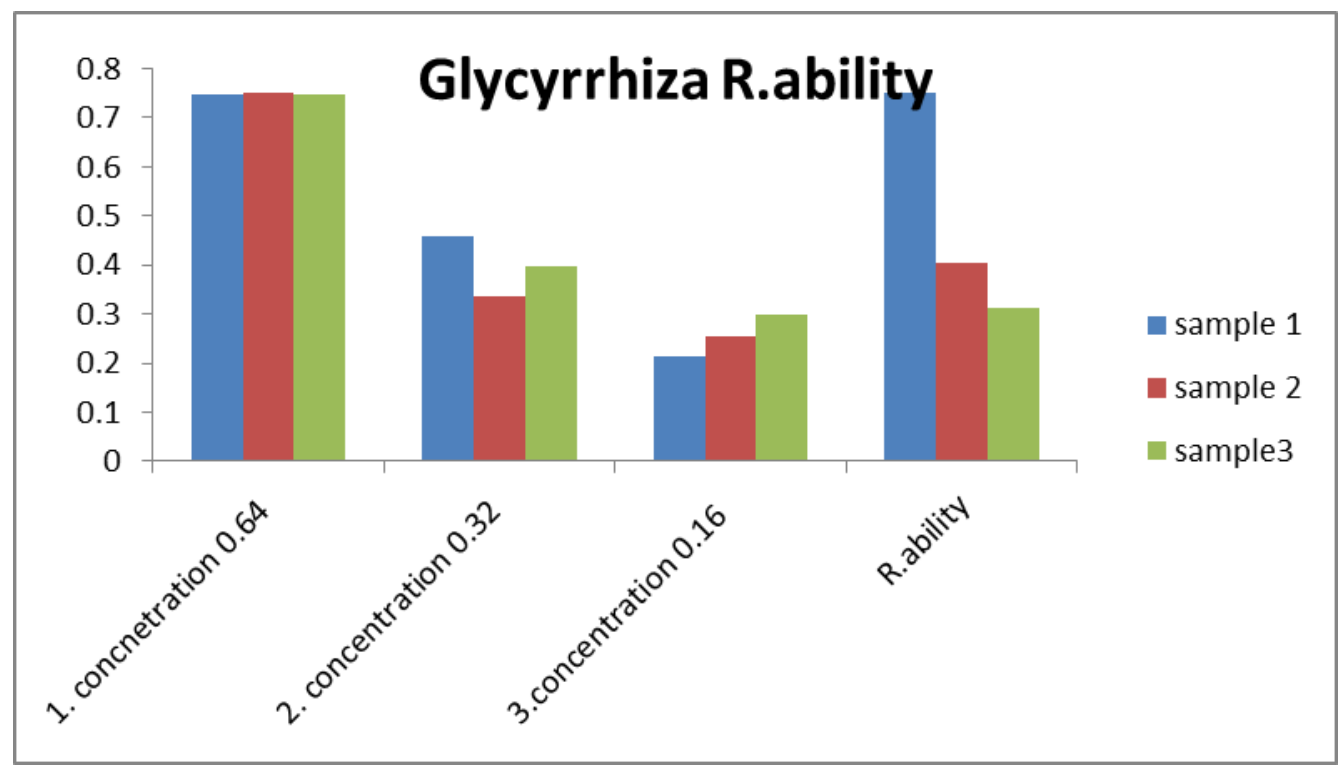

Figure 2. Reductive ability for three different concentrations of Glycyrrihza reductive ability 


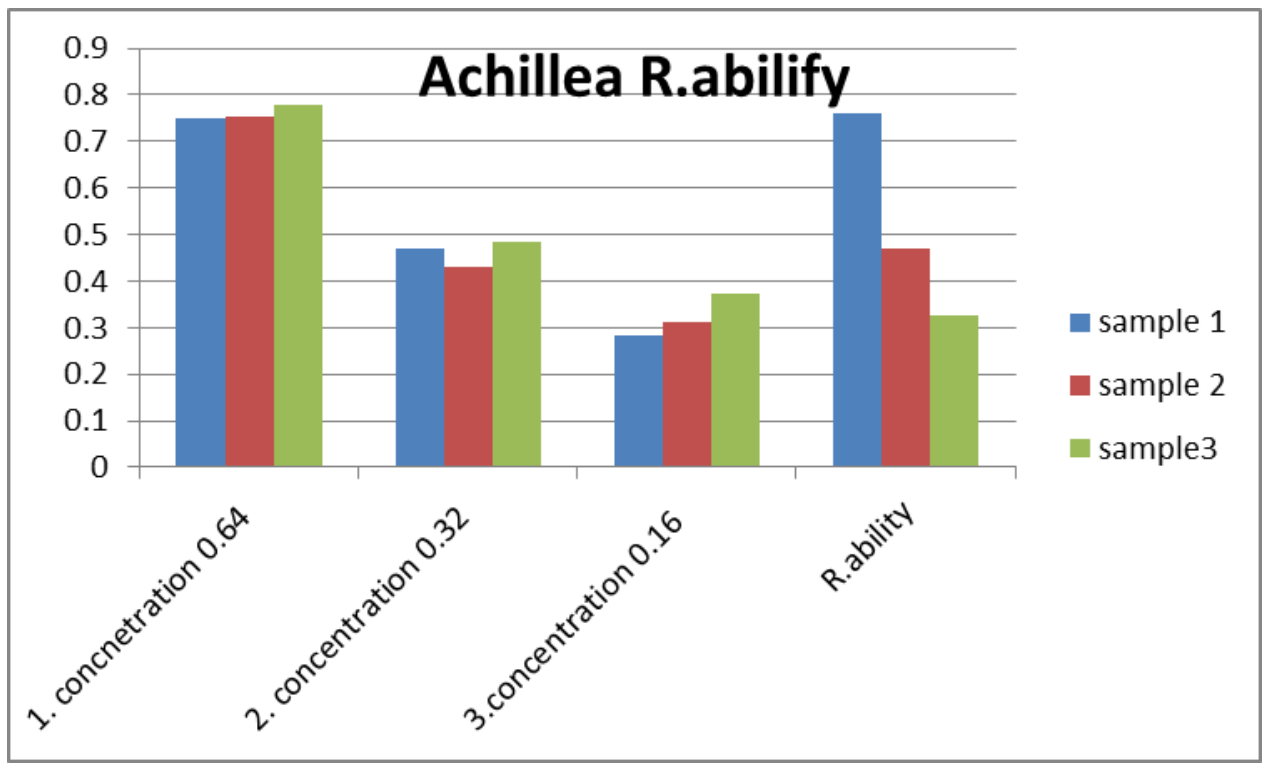

Figure 3. Reductive ability for three different concentrations of Achillea reductive ability

The anti-microbial experiment, were the methanol extract of the two plants in concentration $300,400,500 \mathrm{mg} / \mathrm{l}$ were tested against three types of bacteria which are: Enterobacter sakasaki(E. corona),Klebsiella pheumonia, and Proteus bulgaris. The results in figure 4 indicate:

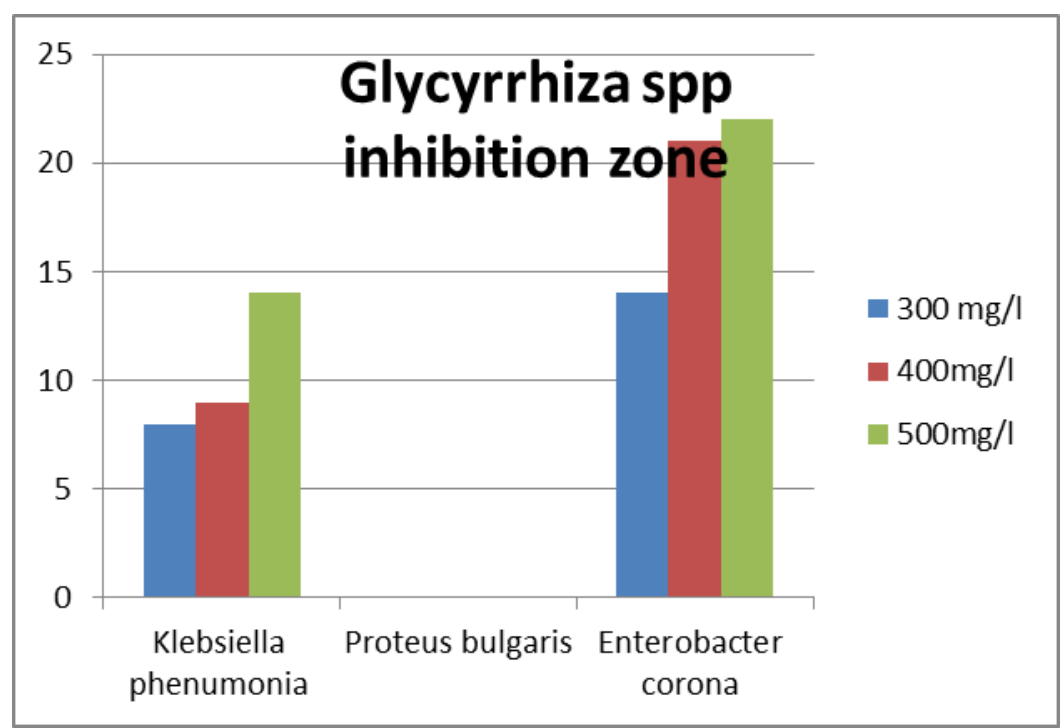

Figure 4. Inhibition zone of the three bacteria in Glycyrrhiza spp exract.

Large inhibition zone found in E.corona followed by K.phenumonia, while no inhibition indicate in P. bulgaris. However, the inhibition zone is increase as concentration of the extract increased.

Similar results found in Achillea spp In figure 5, where all bacteria have inhibition zone even the Proteus bulgaris. 


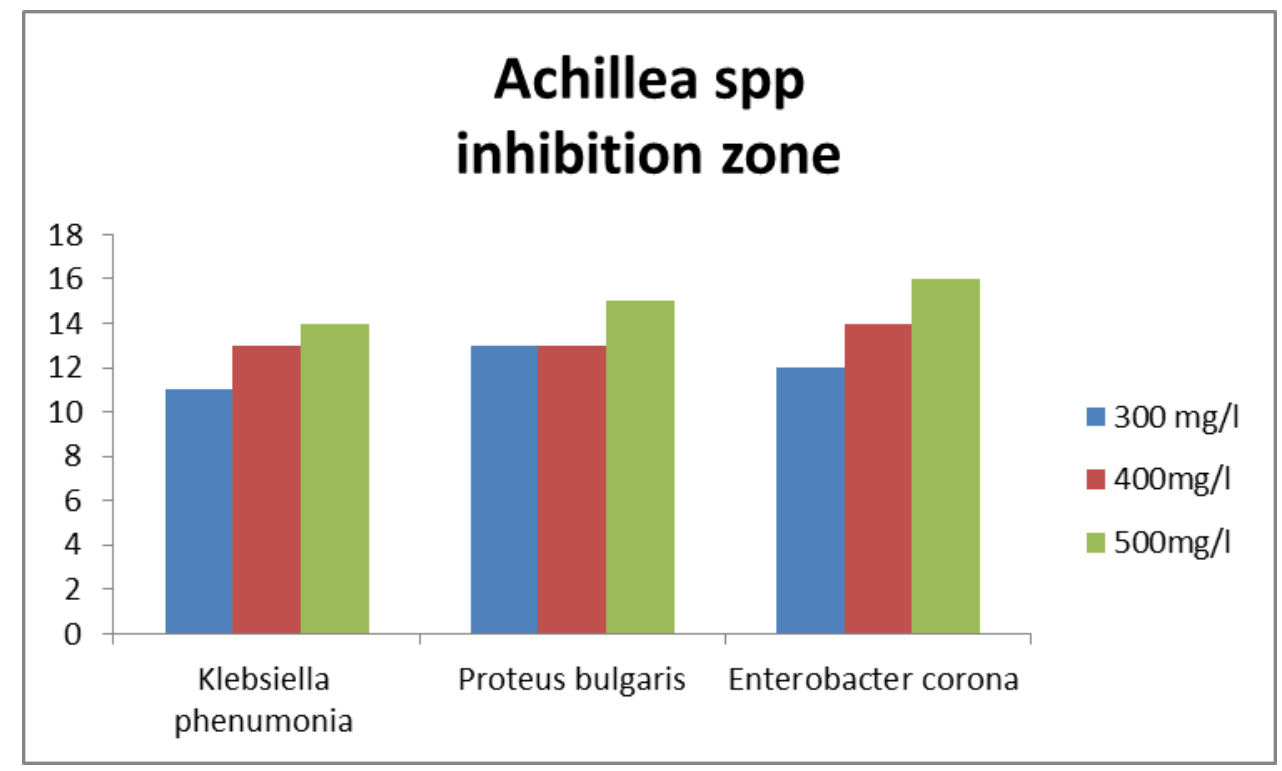

Figure 5. Inhibition zone of the three bacteria in Achillea spp exract.

A very narrow difference was found in A.spp, between the concentration affect in each bacteria as in figure 5 above. The two extracts in the above experiment, indicate high flavenoids which have good antimicrobial activities (Lakshmi T.). This activites may be linked to the presence of essential oil compounds which effect many bacteria in varying degree (Issabeagloo, E. \& Abri, B., 2012).

\section{References}

Butler, M. S., \& Newman, D. J. (2008). Mother Nature's gifts to diseases of man: the impact of natural products on anti-infective, anticholestemics and anticancer drug discovery, in Natural Compounds as Drugs Volume I., Springer. 1-44.

https://doi.org/10.1007/978-3-7643-8117-2_1

Chan, J. M., Wang, F., \& Holly, E. A. (2005). Vegetable and fruit intake and pancreatic cancer in a population-based case-control study in the San Francisco bay area. Cancer Epidemiology and Prevention Biomarkers,. 14(9), 2093-2097.

https://doi.org/10.1158/1055-9965.EPI-05-0226

Chu, Y. H., Chang, C. L., \& Hsu, H. F. (2000). Flavonoid content of several vegetables and their antioxidant activity. Journal of the Science of Food and Agriculture, 80(5), 561-566. https://doi.org/10.1002/(SICI)1097-0010(200004)80:5<561::AID-JSFA574>3.0.CO;2-\#

Cocetta, G., et al. (2015). Methyl jasmonate affects phenolic metabolism and gene expression in blueberry (Vaccinium corymbosum). Physiologia plantarum, 153(2), 269-283.

https://doi.org/10.1111/ppl.12243

Davis, P., Mill, R., \& Tan, K. (1988). Flora of Turkey and the East Aegean Islands, Edinburgh Uni., versity Press.

Duke, J. A., (1992). Handbook of phytochemical constituent grass, herbs and other economic plants., CRC press. 


\section{$\triangle$ Macrothink}

Journal of Biology and Life Science ISSN 2157-6076 2017, Vol. 8, No. 2

Egert, S., \& Rimbach, G. (2011). Which sources of flavonoids: complex diets or dietary supplements? Advances in Nutrition: An International Review Journal, 2(1), 8-14. https://doi.org/10.3945/an.110.000026

Franco, M. N., et al. (2014). Phenolic compounds and antioxidant capacity of virgin olive oil. Food chemistry, 163, 289-298. https://doi.org/10.1016/j.foodchem.2014.04.091

Fu, W., et al., (2010). Antioxidant, free radical scavenging, anti-inflammatory and hepatoprotective potential of the extract from Parathelypteris nipponica (Franch. et Sav.) Ching. Journal of ethnopharmacology, 130(3), 521-528.

https://doi.org/10.1016/j.jep.2010.05.039

Güner, A., et al., (2000). Flora of Turkey and the East Aegean Islands, Vol. 11, Edinburgh Univ. Pres. Edinburg,

Gurib-Fakim, A. (2006). Medicinal plants: traditions of yesterday and drugs of tomorrow. Molecular aspects of Medicine, 27(1), 1-93. https://doi.org/10.1016/j.mam.2005.07.008

Hsu, C.-Y., Chan, Y. -P., \& Chang, J. (2007). Antioxidant activity of extract from Polygonum cuspidatum. Biological research, 40(1), 13-21.

https://doi.org/10.4067/S0716-97602007000100002

Issabeagloo, E., \& Abri, B. (2012). Antimicrobial effects of yarrow (Achillea millefolium) essential oils against Staphylococcus species. African Journal of Pharmacy and Pharmacology, 6(41), 2895-2899. https://doi.org/10.5897/AJPP12.397

Kumar, A., Garg, R., \& Prakash, A. K. (2010). Effect of St. John's Wort (Hypericum perforatum) treatment on restraint stress-induced behavioral and biochemical alteration in mice. BMC complementary and alternative medicine, 10(1), 18.

https://doi.org/10.1186/1472-6882-10-18

Kürkçüoğlu, M., et al. (2003) The essential oil of Achillea falcata L. Flavour and fragrance journal, 18(3), 192-194. https://doi.org/10.1002/ffj.1176

Lakshmi, T., G. R. V., Roy A., \& Aravind, K. S. Yarrow (Achillea millefolium) International Journal of pharmaceutical sciences Rewiew and research 9(2), 136-141

R. M. I. A. -E. (2015). Immuno-enhancement, Antioxidant and Anti-mutagenic Effects of Hypericum triquetrifolium in vitro and in vivo., in medical and molecular Biotechnology feb, Al-Nahrain University Iraq.

Sakanaka, S., Tachibana, Y., \& Okada, Y. (2005). Preparation and antioxidant properties of extracts of Japanese persimmon leaf tea (kakinoha-cha). Food chemistry, 89(4), 569-575.

https://doi.org/10.1016/j.foodchem.2004.03.013

Scientific, C.o., I. R. (1985). Publications, and I. Directorate, The Wealth of India: a dictionary of Indian raw materials \& industrial products. Vol. 1., Publications \& Information Directorate, Council of Scientific \& Industrial Research.

Senatore, F., et al., (2005). Composition and antimicrobial activity of the essential oil of 


\section{Macrothink}

Achillea falcata L.(Asteraceae). Flavour and fragrance journal, 20(3), 291-294.

https://doi.org/10.1002/ffj.1411

Skočibušić, M., et al. (2004). Antibacterial activity of Achillea clavennae essential oil against respiratory tract pathogens. Fitoterapia, 75(7), 733-736.

https://doi.org/10.1016/j.fitote.2004.05.009

Sokmen, A., Jones, B. M., \& Erturk, M. (1999). The in vitro antibacterial activity of Turkish medicinal plants. Journal of ethnopharmacology, 67(1),79-86.

https://doi.org/10.1016/S0378-8741(98)00189-5

Soladoye, M. O., et al. (2010). Ethnobotanical survey of anti-cancer plants in Ogun State, Nigeria. Ann. Biol. Res,. 1(4), 261-273.

Yang, Y., et al. (2013). Natural products chemistry research: progress in China in 2011. Chinese journal of natural medicines, 11(2), 97-109.

https://doi.org/10.1016/S1875-5364(13)60036-9

\section{Copyright Disclaimer}

Copyright for this article is retained by the author(s), with first publication rights granted to the journal.

This is an open-access article distributed under the terms and conditions of the Creative Commons Attribution license (http://creativecommons.org/licenses/by/3.0/). 